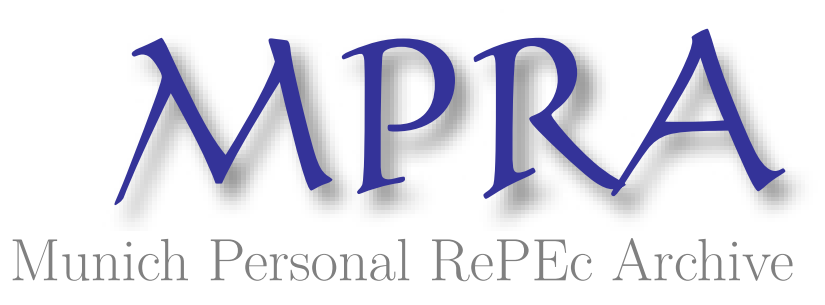

\title{
The Oomph in economic philosophy: a bibliometric analysis of the main trends, from the 1960s to the present
}

Yalcintas, Altug

Ankara University

2013

Online at https://mpra.ub.uni-muenchen.de/44191/

MPRA Paper No. 44191, posted 04 Feb 2013 12:32 UTC 


\title{
The Oomph in Economic Philosophy:
}

\section{A Bibliometric Analysis of the Main Trends, from the 1960s to the Present}

\author{
Altug Yalcintas \\ Department of Economics, Faculty of Political Sciences, Ankara University \\ altug.yalcintas@politics.ankara.edu.tr
}

\begin{abstract}
In this essay, I quantitatively analyze the significance of scholarship in economic philosophy since the 1960s. In order to do so, I examine, through the number of publications and citations, the evolution of the main trends in economic philosophy over a fifty years period. This paper will develop a better conception of how the pathways of major debates, in particular rhetoric of economics (RoE) versus realism in economics $(\mathrm{RiE})$, helped economic philosophy achieve its present status in economics. Viewed through this lens, it is clear that the main trends in the recent history of the discipline have emerged out of the concerns of non-mainstream economists since the 1980s.
\end{abstract}

Keywords: rhetoric of economics, realism in economics, bibliometric analysis

JEL codes: B24, B25, B41 


\section{The Oomph in Economic Philosophy:}

\section{A Bibliometric Analysis of the Main Trends, from the 1960s to the Present}

\section{Introduction}

The number of publications and average number of citations that each publication gets within economic philosophy have increased over the past few decades. There are now a considerable number of independent journals for economic philosophy (Economics and Philosophy, Journal of Economic Methodology, Journal of Philosophical Economics, Erasmus Journal of Philosophy and Economics, Revue de philosophie économique, Oeconomia - History / Methodology / Philosophy, and Economic Thought: History, Philosophy, and Methodology) as well as a number of history of economic thought and heterodox economics journals (such as History of Political Economy, Journal of Economic Issues, Cambridge Journal of Economics, Kyklos etc.). Additionally, printing houses (Routledge and Edward Elgar) are increasingly publishing peer reviewed articles and books on philosophical topics within economics. A number of graduate programs, mainly in Europe, such as those at Erasmus University, the London School Economics, the University of Bayreuth, the University of Helsinki, and at Kingston University, have been launched, granting graduate degrees in economics and philosophy. Scholars in economic philosophy are prominent figures not only in economic philosophy but also in economic history, the history of economic thought, and the philosophy of science. From a scholarly point of view, economic philosophy has become an established field of research in social sciences.

However, in the undergraduate and graduate curricula of economics departments around the world, interest in economic philosophy has been waning. There has been a 
sustained decrease in the numbers of dissertations and hours of courses in which economic philosophy is studied and taught. The job market for economic philosophers is also limited. Is this a contradiction or an inevitable stage in the process of a discipline becoming autonomous? Is economic philosophy separating itself from the standard economics curriculum?

In this essay, I quantitatively analyze the significance of scholarship in economic philosophy since the 1960s. In order to do so, I examine, through the number of publications and citations, the evolution of the main trends in economic philosophy over a fifty years period. This paper will develop a better conception of how the pathways of major debates, in particular rhetoric of economics (RoE) versus realism in economics (RiE), helped economic philosophy achieve its present status in economics. (On the significance of intellectual path dependence in the history of economic thought, see (Yalcintas 2006a, b, 2012, 2013, Forthcoming, Yalcintas and Gurpinar In Progress).) Viewed through this lens, it is clear that the main trends in the recent history of the discipline have emerged out of the concerns of non-mainstream economists since the 1980s.

\section{Scope and limitations}

Economic philosophy is a branch of the philosophy of social science where its practitioners study the epistemological, ontological, and rhetorical issues in economic argumentation such as rationality, positivism, ethics, and causation. In other words, economic philosophy "is to be understood simply as philosophy of science applied to economics" (Blaug 1980 [1987], xi). (For the scope and several definitions of economic philosophy and economic methodology see, Hands 2008, Backhouse 2008, Hausman 1980, 1989, Gerrard 1990, Georgescu-Roegen 1979, Lange 1945) This essay argues that a question such as "What is economic philosophy?" requires one to be curious about measuring the "oomph" of publications in the field. Oomph, 
a term coined by Deirdre McCloskey and Stephen Ziliak (McCloskey 1986, 1992, Ziliak and McCloskey 2004), means that the quantitative significance of scholarship in a particular field of research is as important as its qualitative content. Thus, oomph in economic philosophy refers to the impact of economic philosophers' contributions and implies the measurement of the explanatory power of arguments that scholars in this field put forth. In other words, oomph is the measurement of scholarly attention (Klamer and van Dalen 2002) that an argument or scholar in a specific field gets over any number of years. The significance of the citation analysis in this essay is therefore to provide bibliometric evidence quantifying claims made by prominent authors who have already provided comprehensive definitions of economic philosophy as well as detailed accounts of the breaking down of "received views" in the history of the discipline and economic methodology becoming a "separate science." (Hands 2001b 70-127, Düppe 2011, Ross and Kincaid 2009, Mäki 2008, Davis 2007, Blaug 1980 [1987], Caldwell 1982, Backhouse 1994, Boylan and O'Gorman 1995, Stewart 1991).

A considerable amount of scholarly energy in bibliometric analyses has been spent in the last decade or so on the uses and misuses of impact factors and indexes such as the hindex and the j-index, evaluating the relative performance of universities, journals, and individual scholars. (See for instance (Klein and Chiang 2004, Moed 2005).) This essay is unconcerned with any of these tools and suggests a different direction for acquiring evidence, not based on the performance of individual scholars but based on the evolution of the main trends in economic philosophy over a fifty years period. Bibliometric analysis is a quantitative methodology based on the number of times a particular scholarly work is cited in a specific field. Bibliometric analysis is different from "philosophical analysis" and "rhetorical analysis," a distinction first made by McCloskey (1990a, 1994a). Philosophical analysis is a compilation of techniques to break concepts into smaller pieces so as to eliminate inconsistencies around the issue and produce true (or truer) claims on or about the facts of the 
world. By contrast, rhetorical analysis "does not deal with Truth directly; it deals with conversation" (McCloskey 1985 28). Bibliometric analysis, on the other hand, is a methodology that assesses the significance of a scholar, scholarly work, or journal by way of calculating how frequently others cite an item. Bibliometric analysis is therefore a measurement of scholarly attention. It complements philosophical and rhetorical analyses. However, since it is insufficient to evaluate the scholarly significance of an item solely by the number of subsequent publications that cite it, quantified data should be supplemented by qualified background knowledge in the field of research. Bibliometric analysis is therefore useful in a number of respects but its limitations must be respected. Below, I briefly summarize the scope and limitations of the bibliometric analysis conducted in this essay.

- $\quad$ There are a sufficiently large number of citations in economic philosophy in order to reach conclusions about the main trends within a specific period. It is important to note that the structures of citations in economic philosophy tend to resemble those found in the humanities more closely than the applied sciences, including economics. However, comparing economic philosophy to the philosophy of science or social sciences or indeed any subfield in the humanities is unhelpful due to different structures of citations, such as the noncommonality of co-authorship, limited number of journals in the field, limited number of years that economic philosophy has been autonomous, and limited number of references. Bibliometric analysis in this essay therefore excludes citation ratios among disciplines (that is, “economic philosophy vs. constitutional political economy" or "economic philosophy vs. discourse analysis in sociology") and focuses on citation ratios within economic philosophy.

- $\quad$ One-dimensional evaluation (that is, analyzing only qualitatively or only quantitatively) is misguiding. Figures of publications and citations are only subtle indication of the significance of scholarship in economic philosophy and neither qualitative nor quantitative analysis is entirely sufficient for the job. Often, qualitative analysis partially 
matches qualitative analysis, though mismatch does not refute the significance of either analysis. On the contrary, a mismatch can help increase the sophistication of the overall analysis.

- $\quad$ Citation analysis is sensitive to measurement errors. This is a limitation that mostly applies to online search engines. For instance, some of the articles freely available on the Internet are ranked higher by Google Scholar, such as Social Science Research Network (SSRN) and Munich Personal RePec Archive, than by commercial publishers. Also, Google Scholar fails to distinguish between an article and a book that have the same title, such as McCloskey's “The Rhetoric of Economics” (1983) and The Rhetoric of Economics (1985). Last but not least, Google Scholar does not only count the "scientific" citations a publication gets but it also considers blogs, advertisements, and reviews, some of which are nonacademic.

- $\quad$ Contrary to the scholarly practices in natural science, co-authorship is not a common practice in economic philosophy. Articles in economic philosophy greater than twenty pages in length tend to have a single author, whereas articles of only three or four pages in the natural sciences commonly have more than ten authors. Senior scholars in natural science research groups are often included as an author whereas this practice is rare in economic philosophy.

- $\quad$ More published material in economic philosophy is published in the form of books. Some authors in economic philosophy, such as Alexander Rosenberg and Jon Elster, publish as many books as articles, which are not evaluated in many indexes, including the ISI Web of Knowledge. (ISI's Book Citation Index was launched in November 2011.) By contrast, in natural sciences, far fewer books are published than articles.

- $\quad$ Although ISI is perceived as the "gold standard" in bibliometrics and is indeed a reliable source of data, its limitations must not be overlooked. For instance, ISI only covers 
journal articles that are chosen by the authorities of Thomson Reuters. This is a serious issue for bibliometric analysis because the journals chosen by ISI for evaluation do not include many of the important economic philosophy journals, such as the Journal of Economic Methodology, the Erasmus Journal for Philosophy and Economics, and the Journal of Philosophical Economics.

- $\quad$ EconLit provides a more inclusive and scholarly list of journals in economics. However, EconLit does not provide any quantified data, preventing its use for bibliometric analysis. JSTOR, another scholarly data provider, covers only a handful of economics journals, mainly mainstream journals and almost no philosophical journals in economics, omitting such notable journals as the Journal of Economic Methodology and the Cambridge Journal of Economics.

- In order to acquire the greatest quantity data, I use Google Scholar, EconLit, and RePec where available in order to assess the journal articles and books that are excluded by ISI and JSTOR. I have determined that the Google Scholar scores match closely with the scores provided by ISI and JSTOR, despite the fact that Google Scholar ranks authors and publications according to their popularity among Internet users. This suggests that the lists produced by Google Scholar, ISI, JSTOR, EconLit, and RePec are useful even though these data providers use different algorithms to evaluate the academic performance in terms of citations.

\section{Economic philosophy in citations}

FIGURE 1 HERE ABOUT (Note to the editor and referee(s): metadata available in Excel file)

Figure 1 illustrates the total number of citations of the following scholars between 1960 and 2011: Amartya Sen, Herbert Simon, Jon Elster, Mark Blaug, Geoffrey Hodgson, Deirdre McCloskey, Philip Mirowski, Tony Lawson, Arjo Klamer, Uskali Mäki, Kevin Hoover, 
Daniel Hausman, Bruce Caldwell, Wade Hands, and John Davis. Figure 2 provides a more focused picture of recent debates in economic philosophy. Scholars in this figure are organized into two groups. Group B consist of Hodgson, McCloskey, Mirowski, Lawson, Klamer, Mäki, Hoover, Hausman, Caldwell, Hands, and Davis and Group C McCloskey, Lawson, Klamer, and Mäki. Needless to say, grouping scholars into only two groups despite the wide variety of debates and the richness of their different positions in economic philosophy may appear somewhat simplistic and arbitrary. However, as this essay does not seek neither a "nothing-but" account of the history of economic philosophy nor a clear definition of the borders of the discipline, adding up the citation figures of other important authors, such as Warren Samuels and Roger Backhouse, would not have dramatically altered the relative shape of the trends in both figures, although excluding any one of these 15 influential authors would seriously compromise the quality and content of the analysis conducted here. These authors are considered to represent the main trends of philosophical debate in economics to which scholars from Millian, Popperian as well as pragmatist and realist traditions have contributed in the last five decades.

FIGURE 2 HEREABOUT (Note to the editor and referee(s): metadata available in Excel file)

Figure 1 suggests that there is a great deal more interest in economic philosophy today than there was in the 1960s. Figure 2 implies that the 1980s saw a significant increase in the growth rate of economic philosophy citations. At this time, the debate between RoE and RiE brought scholars from different backgrounds into a debate on the methodology of economic theorizing. Further citations show (see Tables 1 to 4) that (1) McCloskey's “The Rhetoric of Economics" (1983) and The Rhetoric of Economics (1985) proved a catalyst, prompting an intense debate between RoE and RiE until the end of the 1990s, that (2) the debate between RoE and RiE abated in the 2000s, and that (3) today economic philosophy hosts a rich variety 
of debates beyond the RoE and RiE debate, including but not limited to behavioral economics, experimental economics, neuroeconomics, and evolutionism. In the wake of the RoE and RiE debate, economic philosophy broke itself free from a variety of an "unautonomous" issues, originating from subfields of economics, including economic psychology, development economics, "positive economics," and other topics discussed by such economists as Lionel Robbins, Terence Hutchison, and Milton Friedman from the 1950s to 1970s. RoE and RiE helped a new field of research to emerge in the 1980s in which certain debates, such as falsificationism, growth of knowledge, and other issues introduced by philosophers of science, such as Thomas Kuhn, Paul Feyerabend, Imre Lakatos, have taken place with specific attention to economics.

Economic philosophy has therefore become an autonomous discipline, distinct from economics. Bibliometric data suggests that economic philosophy has diverged intellectually, if not totally separated, from the scholarly agenda in the applied fields of economics. Today, economic philosophy has an independent intellectual agenda that only specialized journals of economic philosophy are interested in publishing. The literature on economic philosophy has the capacity to produce new debates and self-regulate the conversations around these debates without referring to the outside literature of computer science and physics. The debate between $\mathrm{RoE}$ and $\mathrm{RiE}$ has functioned as an incubatory process that increased the significance of economic philosophy exponentially. Of course, the debate between RoE and RiE was not the only significant debate in economic philosophy during the relevant period. Economic philosophers have also debated a wide range of issues with regard to evolutionary economics (Witt 1993, 2003, Hodgson 1993, 1998, Vromen 2004), (new and original) institutional economics (Vromen 1995, Rutherford 1994, Hodgson 1988), ethics and justice (Nozick 1975, Rawls 1971), prediction (Friedman 1984 [1953], Boland 1979, Mäki 1992a), abstraction and isolation (Lawson 1989, Mäki 1992b), positivism and postmodernism (Ruccio and Amariglio 
2003, Caldwell 1982), feminism (Ferber and Nelson 1993, Barker and Kuiper 2003), and causation and explanation (Psillos 2002, Mäki 1990, Hoover 2001). However, the debate between RoE and RiE has both long lasted and had significant implications for many other debates in the field. Many economic philosophers after the 1980s either wrote a book, article, or commentary on the subject, engaging themselves in the debate (Rosenberg 1988, Hausman 1998, Hands 1997, Davis 1990, Blaug 1994, Fox 1997). A number of those, who have widely contributed to economic philosophy are philosopher of science and are doing research in departments other than economics, such as Nancy Cartwright, Alexander Rosenberg, and Margaret Archer. For them, the debate between RoE and RiE is worth discussing, at least to the extent that economic philosophy and the history of economics has become an independent and influential field of research in social sciences and humanities.

\section{Debates in economic philosophy: Past and present}

\section{TABLE 1 AND TABLE 2 HEREABOUT}

The emergence of the traditions of $\mathrm{RoE}$ and $\mathrm{RiE}$ are the result of the debates that took place in the intellectual pathways that post-modernism and social constructivism have generated against the positivist philosophy of science since the 1960s (Hands 2001b, 1-12, Boylan and O'Gorman 1995, 8-35). Eminent philosophers of science in the traditions of neo-pragmatism, such as Stanley Fish, George Lakoff, and Richard Rorty, greatly influenced Deirdre McCloskey (McCloskey 1994b, 1990b, 1985), one of the most influential figures in economic philosophy since the 1980 s. However, until the 1980s, economics has not been investigated philosophically as thoroughly and as widely as sociology and political science had been.

Herbert Simon was a leading philosopher of the late twentieth century whose writings were influential not only in psychology, sociology, political science, and computer sciences 
but also in economics. By contrast, Amartya Sen, Friedrich von Hayek, Jon Elster, and Nicholas Georgecsu-Roegen were exceptional economists whose works have been highly cited in many disciplines other than economics. Interestingly, most of the cited articles in economic philosophy, written by eminent economists, such as George Akerlof, Armen Alchian, and Robert Nelson, appeared in "mainstream" economics journals before the 1980s. Table 2 suggests that many of the most cited scholars in economic philosophy, including Milton Friedman, Lionel Robbins, John Maynard Keynes, Joan Robinson, and Terence Hutchison, were economists for whom philosophy was not a primary field of research. Finally, classical economists from the mid-nineteenth century to early twentieth century, such as John Stuart Mill, Karl Marx, and Thorstein Veblen, who were investigating the "economic philosophy" of the social and political life, have not been the most popular sources of philosophical inquiry for economic philosophers, although the epistemological character of economics began to take shape in the eighteenth and nineteenth centuries. It was the $1980 \mathrm{~s}$ when scholars started to think about the specificities of economic science and question the epistemological, ontological, and rhetorical structure of their science.

\section{TABLE 3 AND TABLE 4 HEREABOUT}

Debates on economic methodology in the 1980s and onwards were mainly concerned with the possibility of framing a meta-theory that would help economists produce better economics. Proponents of RoE, such as McCloskey and Klamer, argued that methodological inscriptions in the form of " 3 x 5 cards" were not useful, even if possible, whereas proponents of RiE, including Lawson and Mäki claimed that it was both possible and useful to under-labor for economics and that it would help "[clarify] the cognitive schemes, conceptual tools, etc., at work behind scientific practices" (Lawson, Peacock, and Pratten 1996). The peculiarity of this debate lies in the fact that even if economic methodology were "positively harmful" (Hahn 
1992, see also Backhouse 2010) or “bourgeois" (McCloskey 1985, 24-27), such arguments would have still been philosophical in nature. In other words, even if economic methodology was dead (Hands 2001a), economic philosophy could not be argued useless and impossible for the simple reason that one could only philosophically claim that economic methodology is or is not useless and impossible. It is interesting that one of the first salvos in the field of economic philosophy was an attempt to reduce the efforts of economic philosophy to economic methodology and show that economic methodology is useless for better economics.

It has long been considered that RoE and RiE are two opposed traditions in economic philosophy. Although proponents of RoE and RiE deeply disagree on a number of issues, such as whether economic reality exists independently from each of us or whether better economic methodology is a condition for better economics, one may appraise the significance of the debate between $\mathrm{RoE}$ and $\mathrm{RiE}$ on the basis that both have been significant criticisms of mainstream economics. Indeed, one observes more corresponding concerns between RoE and RiE over the current state of economics than inconsistent views on longstanding philosophical issues.

This essay does not intend to resolve conflicting issues between RoE and RiE. But it is worth mentioning, in passing, that the debate between RoE and RiE, especially during the 1990s, has been shaped more by disagreements about their different world views than on their criticism of mainstream economics. However, as Lawson has argued recently (Lawson 2006), heterodox views in economics could be considered as a division of labor, "as approaching the same totality but with a distinguishing set of concerns, emphases, motivating interests and (so) questions.” As a matter of fact, in Economics and Reality (1997), Lawson mentions McCloskey thrice (five times including footnotes), in Reorienting Economics (2003) only once (thrice including footnotes). (Lawson does not cite Klamer at all.) In none of his works 
is Lawson as critical of McCloskey as he is critical of the deductivist methodology in economics. Moreover, Lawson makes several claims parallel to McCloskey's, such as that "the essential mode of inference sponsored by transcendental realism is neither induction nor deduction but one that can be styled retroduction or abduction or 'as if" reasoning. It consists in the movement, on the basis of analogy and metaphor amongst other things, from a conception of some phenomenon of interest to a conception of some totally different type of thing, mechanism, structure or condition that, at least in part, is responsible for the given phenomenon" (Lawson 1997, 24). Lawson also acknowledges the divergence between “official” methodologies and "unofficial” methodologies (or, in McCloskey's terms, big M and small m methodologies) when he says that there is an "incongruity between official and actual stances on methodology" (Lawson 1997 39). Disagreements between Lawson and McCloskey came later, as Lawson's critical ontology evolved into an anti-postmodernist social theory while McCloskey's criticism has been explicitly a part of postmodernist critical theory.

An unusual tension in economic philosophy is between the traditions of critical realism and scientific realism, in which Mäki and Lawson compete on rather arbitrary grounds. Mäki, a defender of scientific realism, claims that his approach to economic philosophy is a "bottom-up" approach whereas the critical realism of Lawson adopts a "topdown” approach. Though, Lawson claims that Mäki gets him "very wrong." "He is wrong, and possibly mischievous," Lawson claims, "in the way he characterises me, and I think it is misleading, or unhelpful, to present the options in such a dichotomous fashion" (Hirsch and DesRoches 2009).

Despite considerable overlap and philosophical parallelism between these two traditions of realism in economics (Hodge 2007, Hands 2001b, 320-334), it is not perfectly 
clear how their efforts to show the inadequacy of orthodox views in economics are distinct. Citation figures cannot illustrate the attention that the authors pay to the differences in their philosophies. In an interview, Mäki claims, without providing evidence, that "as I tried to apply Bhaskar's ideas in my emerging realist philosophy of economics, within a few years I abandoned them as too simplistic for the purpose (as you know, some years later Bhaskar's ideas were discovered by Tony Lawson and used in arguments that I think distort facts about economics)" (Mirales-Flores 2008, italics added). Of course, Lawson disagreed: "So the distinction that Mäki draws between his approach and mine is not right; nor do I believe it is especially helpful. I am pleased you asked the question. It gives me the opportunity to express a view on the matter in this forum where Mäki is clearly influential. Perhaps Mäki will think I misrepresent him in turn. I hope I do not. But if so I hope he replies" (Hirsch and DesRoches 2009). Mäki has not yet replied.

I contend that the distinctions between Mäki and Lawson's forms of realism are rather "subjective" and that there are few, if any, "deep" conflicting issues between the two eminent scholars. As I argued before, main trends in the recent history of economic philosophy have emerged out of the concerns of non-mainstream economists since the 1980s, largely developing by utilizing the opposing views from within economics discipline. However, nonintellectual causes have also assisted in the emergence of diverging intellectual pathways within the discipline. External factors, such as the political, social, and geographical positions of scholars, have driven debates throughout the history of economic philosophy just as much as internal debates have. Ideological schisms, personal tensions, and intellectual networks, which are often proclaimed as driving the motors of dispute in the history of economics, are all determinants of variation of theories and viewpoints in economic philosophy. Any of Mäki and Lawson's students and colleagues would adamantly assert that the controversy here is mainly due to "deep troubles" in the intellectual networks of scientific realism and critical 
realism. As Randall Collins writes in The Sociology of Philosophies (1998, 880-881) "[t]he very concept of a deep trouble combines an element of realism with its inevitable consequence of splitting realities. Deep troubles are discovered by the network, not merely contrived; they are obdurate and unmalleable; they constrain and shape the path of the philosophical network across generations ... Even philosophy, ..., the field whose creativity battens on self-propagating difficulties, makes discoveries about a reality of its own.”

\section{Concluding remarks}

In this essay, I have used bibliometric data in conjunction with background knowledge in economic philosophy to argue that economic philosophy has received attention of many heterodox scholars, from within and outside of economics, in a continuously increasing fashion since the 1960s. The 1980s gave rise to a general interest in RoE, criticizing mainstream theorizing (i.e. positivist views) in economics. The subsequent debate between RoE and RiE took place during the formative years of economic philosophy, during which economic philosophy separated itself into an autonomous field of research.

Economic philosophy flourished, based on general criticisms of the conditions of economics from the 1980s onwards. As Lawson (2006) argues, RoE and RiE can and should be considered a division of labor in heterodox economics, among many other streams of thought. Perhaps, one could even argue that this debate was the "birth pangs" of economic philosophy achieving autonomy. Now, the question is as follows: Will economic philosophy continue to host a genre of scholarly criticism from within economics or will it become a source of conservatism, serving to develop mainstream economics? Only time will tell.

\section{References}


Backhouse, Roger E. 1994. New Directions in Economic Methodology. London and New York: Routledge.

Backhouse, Roger E. 2008. "Methodology of Economics." In The New Palgrave Dictionary of Economics, edited by Steven N. Durlauf and Lawrence E. Blume. Basingstoke: Palgrave Macmillan.

Backhouse, Roger E. 2010. "Methodology in Action." Journal of Economic Methodology no. $17(1): 3-15$.

Barker, Drucilla K., and Edith Kuiper. 2003. Toward a Feminist Philosophy of Economics. London and New York: Routledge.

Blaug, Mark. 1980 [1987]. The Methodology of Economics: How Economists Explain. Cambridge: Cambridge University Press.

Blaug, Mark. 1994. "Why I am not a Constructivist: Confessions of an Unrepentant Popperian." In New Directions in Economic Methodology, edited by Roger Backhouse, 109-136. London: Routledge.

Boland, Lawrence A. 1979. "A Critique of Friedman's Critics." Journal of Economic Literature no. 17 (2):503-522.

Boylan, Thomas A., and Paschal F. O'Gorman. 1995. Beyond Rhetoric and Realism in Economics: Towards a Reformulation of Economic Methodology. Economics as Social Theory series. London and New York: Routledge.

Caldwell, Bruce. 1982. Beyond Positivism: Economic Methodology in the Twentieth Century. London: Allen \& Unwin.

Collins, Randall. 1998. The Sociology of Philosophies: A Global Theory of Intellectual Change. Cambridge, Mass.: Harvard University Press.

Davis, John B. 1990. "Rorty's Contribution to McCloskey's Understanding of Conversation as the Methodology of Economics." Research in the History of Economic Thought and Methodology no. 7:73-85.

Davis, John B. 2007. "The Turn in Economics and the Turn in Economic Methodology." Journal of Economic Methodology no. 14 (3):275-290.

Düppe, Till. 2011. "How Economic Methodology Became a Separate Science." Journal of Economic Methodology no. 18 (2):163-176.

Ferber, Marianne A., and Julie A. Nelson. 1993. Beyond Economic Man: Feminist Theory and Economics. Chicago: The University of Chicago Press.

Fox, Glenn. 1997. Reason and Reality in the Methodologies of Economics: An Introduction. Cheltenham: Edward Elgar.

Friedman, Milton. 1984 [1953]. "The Methodology of Positive Economics." In The Philosophy of Economics: An Anthology, edited by Daniel M. Hausman, 180-213. Cambridge; New York and Sydney: Cambridge University Press.

Georgescu-Roegen, Nicholas. 1979. "Methods in Economic Science." Journal of Economic Issues no. 13 (2):317-328.

Gerrard, Bill. 1990. "On Matters Methodological in Economics: Review Article." Journal of Economic Surveys no. 4 (2):197-219.

Hahn, Frank. 1992. "Reflections." Royal Economic Society Newsletter no. 77 (April).

Hands, D. Wade. 1997. "Emprical Realism as Meta-Method: Tony Lawson on Neoclassical Economics." Ekonomia no. 1:39-53.

Hands, D. Wade. 2001a. "Economic Methodology is Dead - Long Live Economic Methodology: Thirteen Theses on the New Economic Methodology." Journal of Economic Methodology no. 8 (1):49-63.

Hands, D. Wade. 2001b. Reflection without Rules: Economic Methodology and Contemporary Science Theory. Cambridge: Cambridge University Press. 
Hands, D. Wade. 2008. "Philosophy and Economics." In The New Palgrave Dictionary of Economics, edited by Steven N. Durlauf and Lawrence E. Blume. Basingstoke: Palgrave Macmillan.

Hausman, Daniel. 1998. "Problems with Realism in Economics." Economics and Philosophy no. $14(2): 185-213$.

Hausman, Daniel M. 1980. "How to Do Philosophy of Economics." PSA: Proceedings of the Biennial Meeting of the Philosophy of Science Association no. 1980:353-362.

Hausman, Daniel M. 1989. "Economic Methodology in a Nutshell." The Journal of Economic Perspectives no. 3 (2):115-127.

Hirsch, Clemens, and C. Tyler DesRoches. 2009. "Cambridge Social Ontology: An Interview with Tony Lawson " Erasmus Journal for Philosophy and Economics no. 2 (1):100122.

Hodge, Duncan. 2007. "Economics, Realism, and Reality: A Comparison of Mäki and Lawson." Cambridge Journal of Economics no. 32 (2):163-202.

Hodgson, Geoffrey Martin. 1988. Economics and Institutions:A Manifesto for a Modern Institutional Economics. Philadelphia: University of Pennsylvania Press.

Hodgson, Geoffrey Martin. 1993. Economics and Evolution: Bringing Life Back into Economics. Ann Arbor: University of Michigan Press.

Hodgson, Geoffrey Martin. 1998. "The Approach of Institutional Economics." Journal of Economic Literature no. 36 (1):166-192.

Hoover, Kevin D. 2001. Causality in Macroeconomics. Cambridge: Cambridge University Press.

Klamer, Arjo, and Hendrik P. van Dalen. 2002. "Attention and the Art of Scientific Publishing." Journal of Economic Methodology no. 9 (3):289-315.

Klein, Daniel B., and Eric Chiang. 2004. "The Social Science Citation Index: A Black Boxwith Ideological Bias." Econ Journal Watch no. 1 (1):134-165.

Lange, Oscar. 1945. "The Scope and Method of Economics." The Review of Economic Studies no. 13 (1):19-32.

Lawson, Clive, Mark Peacock, and Stephen Pratten. 1996. "Realism, Underlabouring and Institutions." Cambridge Journal of Economics no. 20 (1):137 51.

Lawson, Tony. 1989. "Abstraction, Tendencies and Stylised Facts: A Realist Approach to Economic Analysis." Cambridge-Journal-of-Economics no. 13 (1):59-78.

Lawson, Tony. 1997. Economics and Reality. London: Routledge.

Lawson, Tony. 2003. Reorienting Economics. London: Routledge.

Lawson, Tony. 2006. "The Nature of Heterodox Economics." Cambridge Journal of Economics no. 30 (4):483-505.

Mäki, Uskali. 1990. "Scientific Realism and Austrian Explanation." Review of Political Economy no. 2 (3):310-344.

Mäki, Uskali. 1992a. "Friedman and Realism." Research in the History of Economic Thought and Methodology no. 10:171-195.

Mäki, Uskali. 1992b. "On the Method of Isolation in Economics." Poznan Studies in the Philosophy of the Sciences and the Humanities no. 26:319-354.

Mäki, Uskali. 2008. "Method and Appraisal in Economics, 1976 - 2006." Journal of Economic Methodology no. 15 (4):409-423.

McCloskey, Deirdre N. 1983. "The Rhetoric of Economics." Journal of Economic Literature no. $21(2): 481-517$.

McCloskey, Deirdre N. 1985. The Rhetoric of Economics. Madison, Wis.: University of Wisconsin Press. 
McCloskey, Deirdre N. 1986. "Why Economic Historians Should Stop Relying on Statistical Tests of Significance and Lead Economists and Historians into the Promised Land." Newsletter of the Cliometrics Society no. 2 (2):5-8.

McCloskey, Deirdre N. 1990a. "Formalism in the Social Sciences, Rhetorically Speaking." The American Sociologist no. 21 (1):3-19.

McCloskey, Deirdre N. 1990b. If You're so Smart: The Narrative of Economic Expertise. Chicago: University of Chicago Press.

McCloskey, Deirdre N. 1992. "Other Things Equal: The Bankruptcy of Statistical Significance." Eastern Economic Journal no. 18 (3):359-361.

McCloskey, Deirdre N. 1994a. "How to Do a Rhetorical Analysis and Why." In New Directions in Economic Methodology, edited by Roger Backhouse, 319-371. London and New York: Routledge.

McCloskey, Deirdre N. 1994b. Knowledge and Persuasion in Economics. Cambridge: Cambridge University Press.

Mirales-Flores, Luis. 2008. "Realism from the 'Lands of Kaleva': An Interview with Uskali Mäki " Erasmus Journal for Philosophy and Economics no. 1 (1):124-146.

Moed, Henk. 2005. Citation Analysis in Research Evaluation. Dordrecht: Springer.

Nozick, Robert. 1975. Anarchy, State, and Utopia. Oxford: Blackwell.

Psillos, Stathis. 2002. Causation and Explanation: Mcgill Queens University Press.

Rawls, John. 1971. A Theory of Justice. Cambridge, Mass.: Harvard University Press.

Rosenberg, Alexander. 1988. "Rhetoric Is Not Important Enough for Economists to Bother About." Economics and Philosophy no. 4 (1):173 75.

Ross, Don, and Harold Kincaid. 2009. "Introduction: The New Philosophy of Economics." In The Oxford Handbook of Philosophy of Economics, edited by Don Ross and Harold Kincaid, 3-32. Oxford: Oxford University Press.

Ruccio, David, and Jack Amariglio. 2003. Postmodern Moments in Economics. Princeton: Princeton University Press.

Rutherford, M. 1994. Institutions in Economics: The Old and the New Institutionalism. Cambridge: Cambridge University Press.

Stewart, Ian M. T. 1991. "The Role of the Methodologist." In Companion to Contemporary Economic Thought, edited by David Greenaway, Micheal Bleaney and Ian M. T. Stewart, 7-24. London and New York: Routledge.

Vromen, Jack. 2004. "Conjectural Revisionary Economic Ontology: Outline of an Ambitious Research Agenda for Evolutionary Economics." Journal of Economic Methodology no. 11 (2):213-247.

Vromen, Jack J. 1995. Economic Evolution: An Enquiry into the Foundations of New Institutional Economics. London and New York: Routledge.

Witt, Ulrich. 1993. Evolutionary Economics, The International library of critical writings in economics. Aldershot: Edward Elgar.

Witt, Ulrich. 2003. The Evolving Economy: Essays on the Evolutionary Approach to Economics. Northampton, MA: Edward Elgar Pub.

Yalcintas, Altug. 2006a. "Historical Small Events and the Eclipse of Utopia: Perspectives on Path Dependence in Human Thought." Culture, Theory, and Critique no. 47 (1):53-70.

Yalcintas, Altug. 2006b. "Otomobillerimiz var, Pizzalarımız da... Deirdre McCloskey ile bir Söyleşi [We have automobiles, and pizzas, too: An Interview with Deirdre McCloskey]." Mulkiye Dergisi no. 30 (251):185-197.

Yalcintas, Altug. 2012. "A Notion Evolving: From 'Institutional Path Dependence' to 'Intellectual Path Dependence'." Economics Bulletin no. 32 (2):1091-198. 
Yalcintas, Altug. 2013, Forthcoming. "The Problem of Epistemic Cost: Why Do Economists Not Change Their Minds (About the 'Coase Theorem')?" American Journal of Economics and Sociology no. 72 (5).

Yalcintas, Altug, and Erkan Gurpinar. In Progress. "One Long Argument in Economics: Revisiting Lawson's Critical Ontology and Veblen's Philosophical Legacy."

Ziliak, Stephen Thomas, and Deirdre N. McCloskey. 2004. "Significance Redux." Journal of Socio-economics no. 33 (5):665-675. 

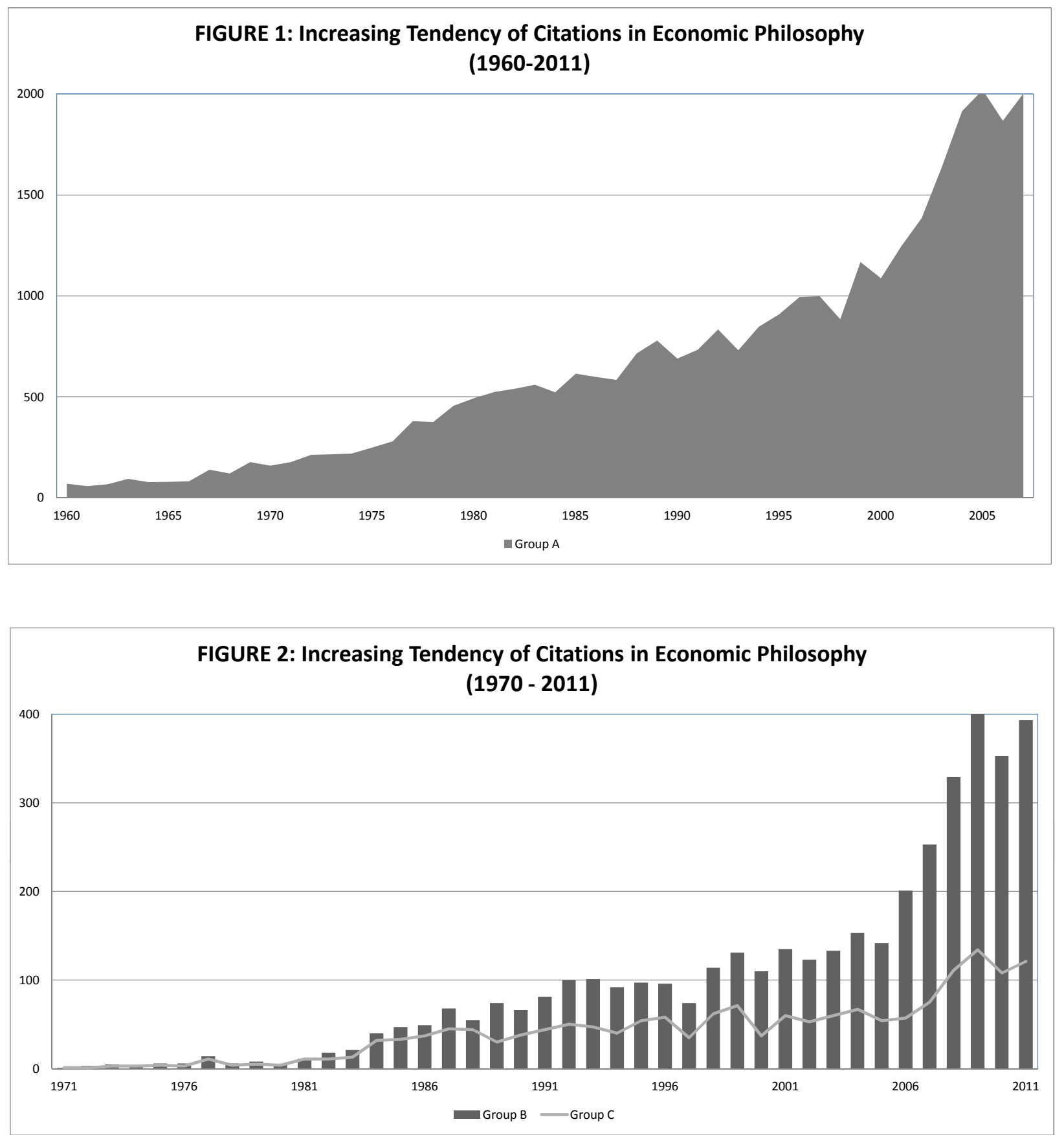

Figure 1 and 2, prepared in December 2012, provide graphs regarding the evolution of citation figures in economic philosophy over years. Only ISI articles are covered. Authors with identical surnames (such as Elster, Simon, and Lawson) who publish in areas other than economic philosophy are checked and irrelevant citations are singled out. 
Table 1: Some of the Most Cited Articles in Economic Philosophy, before 1980s

Title

The Market for "Lemons": Quality Uncertainty and the Market Mechanism The Use of Knowledge in Society

Uncertainty, Evolution, and Economic Theory

The Methodology of Positive Economics *

Rational Fools

The Simple Economics of Basic Scientific Research

General Systems Theory - The Skeleton of Science

Why is Economics not an Evolutionary Science?

Elements of a Theory of Human Problem Solving

The Empirical Status of Human Capital Theory

Energy and Economic Myths

On the Definition of Political Economy **

The Social and Economic Roots of Newton's Principia ***

A Critique of Friedman's Critics

Situational Determinism in Economics

Economic Models

What is Truth in Economics ****

Friedman and Machlup on the Significance of Testing Economic Assumptions

The "F-Twist" and the Methodology of Paul Samuelson

The "Structure of Revolutions" in Economic Thought

\section{Full Reference}

G. A. Akerlof. 1970. QJE 84 (3): 488-500

F. Von Hayek. 1945. AER 35 (4): 519-530

A. Alchian. 1950. JPE 58 (3): 211-221

M. Friedman. 1953. Chicago

A. Sen. 1977. Phil. \& Pub. Aff. 6 (4): 317-344

R. R. Nelson. 1959. JPE 67 (3): 297-306

K. E. Boulding. 1956. Man. Sc. 2 (3): 197-208

T. Veblen. 1898. QJE 12 (4): 373-397

H. Simon et al. 1959. Pscho. Rev. 65 (3): 151-166

M. Blaug. 1976. JEL 14 (3): 827-855

G. Roegen. 1975. Southern EJ 41 (3): 347-381

J. S. Mill. 1874. Longmans

B. Hessen. 1931.

L. Boland. 1979. JEL 17 (2): 503-522

S. J. Latsis. 1972. B J of P of Sc 23 (3): 207-245

A. Gibbard and H. V. Varian. 1978. J of Phil. 75 (11): 664-677

F. Knight. 1940 JPE 48: 1-32

Melitz, J. 1965. JPE 73: 37-60

S. Wong. 1973. AER 63 (3): 312-325

M. Bronfenbrenner. 1971. HOPE 3: 136-151
Google Scholar

15772

8928
3945

3945

2790

2790

1974

1317

1008
ISI

* Originally a chapter of author's Essays in Positive Economics (1953)

** Originally a chapter of author's Essays on Some Unsettled Questions of Political Economy (1874

*** Originally a chapter of Bukharin's Science at the Crossroads (1931)

**** Google Scholar does not produce a seperate result for this article but the author's On the History and Method of Economics (1956) of which this article was a par

Selected articles and books in Tables 1 to 4, prepared in December 2012, are the selected authors' most cited works in economic philosophy. Tables are not meant to be all-inclusive. For instance, citations to the works of scholars publishing in the fields of philosophy of science, history of science, and sociology of science, such as Thomas Kuhn, Robert Merton, Pierre Bourdieu, and Roy Bhaskar, are excluded. Scholars, such as Ronald Coase, Paul Samuelson, and Kenneth Arrow, who have been cited in several subdisciplines of economics, are also excluded although these scholars have been cited economic philosophy as well. 
Table 2: Some of the Most Cited Books in Economic Philosophy, before 1980s

Title *

Administrative Behavior

A Treatise on Probability

The Entropy Law and the Economic Process

Essays in Positive Economics

Collective Choice and Social Welfare

An Essay on the Nature and Significance of Economic Science

Ulysses and Sirens: Studies in Rationality and Irrationality

The Image: Knowledge in Life and Society

The Production and Distribution of Knowledge in the US

The Methodology of Economics

A Contribution to the Critique of Political Economy

Three Essays on the State of Economic Science

Economic Philosophy

The Place of Science in Modern Civilisation and Other Essays

Essays on Some Unsettled Questions of Political Economy

The Foundations of Economic Method: A Popperian Perspective

Rational Economic Man: A Philosophical Critique of Neo-Classical Economics

The Significance and Basic Postulates of Economic Theory

Time in Economics

Ideology and Method in Economics

\section{Full Reference **}

H. Simon. 1976. CUP

J. M. Keynes. 1921. Macmillan

G. Roegen. 1971. CUP

M. Friedman. 1953. Chicago

A. Sen. 1970. Holden Day

L. Robbins. 1932. Macmillan

J. Elster. 1979. Cambridge

K. Boulding. 1956. Michigan

F. Machlup. 1962. Princeton

M. Blaug. 1962. Richard D. Irwin Inc.

K. Marx. 1859. Progress

T. Koopmans. 1957. McGraw Hill

Jobinson. 1962. Aldine Pub. Co.

T. Veblen. 1919. BW Huebsch

J. S. Mill. 1844. Longmans

L. Boland. 1982. George Allen \& Unwin

M. Hollis and E. Nell. 1975. CUP

T. Hutchison. 1938. Macmillan

G. L. Shakle. 1967. North-Holland

H. Katouzian. 1980. Macmillan

\section{Google Scholar}

15621

7759

3955

3739

3540

3230

2483

2448

2401

2091

1618

1405

1014

677

431

406

381

377

* Handbooks and edited books are excluded.

** Dates indicate the year the first edition of the book is published. Books listed here are the most cited books of the authors in

economic philosophy. 
Table 3: Some of the Most Cited Articles in Economic Philosophy, 1980s and on

Title

Why a Diagram is (Sometimes) Worth Ten Thousand Words

The Rhetoric of Economics

Social Norms and Economic Theory

The Approach of Institutional Economics

Rationality and Social Choice

Data Mining Reconsidered

The Making of an Economist

Uncertainty and Economic Analysis

Where are We Now in the Economics of Educatio

On the Futility of Criticizing the Neoclassical Maximization Hypothesis

The Present State of Institutional Economics

Hayek and Socialism

On the Method of Isolation in Economics

Size Matters

Physics and the "Marginalist Revolution"

One Quarter of GDP is Persuasion

How to Combine Rhetoric and Realism in the Methodology of Economic

If Economics isn't Science, What is It?

If Mathematics is Informal, Then Perhaps We Should ...

A Paradox of Budgets

* The sum of the article and the book, both of which were published with the same titl
Full Reference

H. Simon and J. Larkin. 1987. Cogn. Sci. 11: 65-99

D. McCloskey. 1983. JEL 21 (2): 481-517

J. Elster. 1989. JEP 4 (3): 99-117

G. Hodgson. 1998. JEL 36 (1): 166-192

A. Sen. 1995. AER 85 (1): 1-24

K. Hoover and S. Perez. 1999. Econometrics J 2 (2): 167-191

A. Klamer. 1987. JEP 1 (2): 95-111

T. Lawson. 1985. EJ 95 (380): 909-927

M. Blaug. 1985. Econ of Ed Rev 4 (1): 17-28

L. Boland. 1981. AER 71 (5): 1031-1036

W. Samuels. 1995. CJE 19 (4): 569-590

B. Caldwell. 1997. JEL 35 (4): 1856-1890

U. Maki. 1992. Poznan Studies ... 26: 319-354

S. Ziliak and D. McCloskey. 2004. J of So-Econ 33: 527-546

P. Mirowski. 1984. CJE 8 (4): 361-379

A. Klamer and D. McCloskey. 1995. AER 85 (2): 191-195

U. Maki. 1988. E\&P 4 (1): 89-109

A. Rosenberg. 1983. Phil. Forum 14 (3-4): 296-314

R. Backhouse. 1998. El 108 (451): 1848-1858

P. Mirowski and W. Hands. 1998. HOPE 30: 260-292
Google Scholar

|SI

255

2426 *

1074

1041

513

380

253

241

234

224

192

190

180

173
163

163
139

94

83

81

81
930

247

305

211

133

78

68

45

50

-

57

31
21

13 
Table 4: Some of the Most Cited Books in Economic Philosophy, 1980s and on *

Title

The Rhetoric of Economics

The Methodology of Economics, Or How Economists Explain

Nuts and Bolts for the Social Sciences

Economics and Reality

Economics and Evolution: Bringing Life Back into Economics

Bounded Rationality in Macroeconomics

Beyond Positivism

The Inexact and Separate Science of Economics

Machine Dreams: Economics Becomes a Cyborg Science

Knowledge and Class: A Marxian Critique of Political Economy

Rules and Choice in Economics

The Foundations of Economic Method

Feminism, Objectivity, and Economics

Reflections without Rules

Economics: Mathematical Politics or Science of Diminishing Returns

The Theory of the Individual in Economics

Conversations with Economists

Truth versus Precision in Economics

Causality in Macroeconomics

The Economic Laws of Scientific Research

* Handbooks and edited books are excluded.

** Dates indicate the year the first edition of the book is published. Books listed here are the most cited books of the authors in economic philosophy.

*** The sum of the article and the book, both of which were published with the same title
Full Reference $* *$

D. McCloskey. 1985. Wisconsin.

M. Blaug. 1980. CUP

J. Elster. 1989. CUP

T. Lawson. 1997. Routledge

G. Hodgson. 1997. Michigan

T. Sargent. 1993. OUP

B. Caldwell. 1982. Routledge

D. Hausman 1992 CUP

P. Mirowski. 2002. CUP

S. Resnick and R. Wolff. 1987. Chicago

V. Vanberg. 1994. Routledge

L. Boland. 1982. Routledge

J. Nelson. 1996. Routledge

W. Hands. 2001. CUP

A. Rosenberg. 1992. Chicago

J. Davis. 2003. Routledge

A. Klamer. 1984. Rowman and Littlefield

T. Mayer. 1993. CUP

K. Hoover. 2001. CUP

T. Kealey. 1996. CUP

\section{Google Scholar}

$2426 * * *$

2091

1761

1581

1561

1266

913

895

667

579 